\title{
Test Research on Pile Foundation under Vertical and Horizontal Loads in Landslide
}

\author{
WANG Zhi-long ${ }^{1, a}$, ZHANG Jian-wei, ${ }^{2, b}$ \\ ${ }^{1}$ School of Civil Engineering and Architecture , Henan University, Kaifeng, 475004,China \\ ${ }^{2}$ School of Civil Engineering and Architecture, Henan University, Kaifeng, 475004,China \\ a23385604@qq.com, bjw101_0@163.com
}

\begin{abstract}
Keywords: Pile foundation; landslide; vertical load; horizontal load; bearing characteristics.
Abstract. Pile foundation of buildings have not only bear the load from the upper structure, but also bear the earth pressure from the slope, its load transfer mechanism is more complicated. Hence, it is important to study the pile-slope interaction mechanism, and to improve the lateral capacity of pile foundation. This paper presents the experimental study on the bearing characteristics at different locations in landslide, which measured the pile horizontal displacement, bending moment and soil pressure. The results show that: the pile locate at the top of the slope has the maximum horizontal displacement when only under vertical load; test pile under vertical load, horizontal load on the horizontal displacement of the pile less affected; when vertical load unchanged, with the depth increases, the earth pressure value was " $S$ " type change; bending moment decreases after the first increase in depth, appears reverse moment in a certain depth.
\end{abstract}

\section{Introduction}

Pile by both vertical loads and lateral loads have attracted the attention of many domestic and foreign scholars. Anagnostopoulos [1] through the model test of single pile under vertical and lateral loads of relationships. W D Guo [2] and so on through the model test of the upper layer of soil lateral movement of the pile moment, soil reaction force of the impact, found that the maximum bending moment and soil reaction force are significantly less than the top of the pile no case of vertical load. Liang Fa-yun[3] for single pile under vertical and horizontal loads combined action theoretical analysis showed that vertical loads laterally loaded piles make the bending moment on the increase or increases lateral deformation pile. Liu Cheng-xue [4] introduced free Galerkin method, method of stress analysis under inclined loads Piles in-depth analysis and research, and the development of materials for linear elastic, elastoplastic material discontinuities and material issues of non- Galerkin analysis procedures. Gong xian-bin[5] designed $45^{\circ}, 60^{\circ}, 75^{\circ}$ slope under three different indoor models steep high and steep slope cross section of bridge pile foundation bearing test, through the process of carrying pile top displacement, pile internal force and pile lateral soil pressure, load transfer law on vertical and horizontal loads under the pile, the internal force distribution and pressure distribution of the soil pile side were studied. Zheng Gang, Wang Li [6] inclined pile of Tianjin, a high-rise building projects in different degrees of vertical load test conducted on-site, on the basis of test results on the use of ABAQUS finite element analysis software to simulate the effects of different vertical, under different soil conditions pile load bearing capacity of the vertical transfer and law degree change. The load transfer characteristics and variability of pile on hillside under complex loads has been simulated based on ABAQUS by Zhang Jian-wei[7]. Ma Jin-dong [8] and other human-shaped cross-sectional study variable force characteristics of reinforced concrete piles under lateral loads were calm water pile load scale model tests. Previous studies mostly located in the ground level for the pile, or as a pile, and in engineering practice will encounter many of the buildings built on the slopes, pile subjected to complex load situation, to reveal the complex on the slopes loaded pile bearing characteristics, this paper will conduct research on the pile bearing characteristics at different locations on the slopes by model tests. 


\section{Model test}

\section{Test material parameters}

The test is based on the theory of similarity than in laboratory models groove structure (length $\times$ width $\times$ height $=4 \mathrm{~m} \times 2 \mathrm{~m} \times 3 \mathrm{~m}$ ) filling layered soil slopes, the test soil from the Kaifeng pink sand. The test sand to fill in the post-stratification model $15 \mathrm{~cm}$ tank and compacted soil test carried out after the filling is completed, access to physical property and mechanical parameters of the soil (Table 1), and then turn in the model tank arrangement of a reinforced concrete piles, pile parameters in Table 2. In every $0.14 \mathrm{~m}$ pile surface strain gauge symmetry paste (order of A1, B1, C1, D1, E1, F1, G1 and A2, B2, C2, D2, E2, F2, G2), were arranged 7 pairs, calculated by reading pile stress distribution and thus can calculate the moment distribution along the pile. Miniature earth pressure cells embedded in the soil around the pile and strain gauges corresponding position obtained by earth pressure cell reading pile lateral soil pressure distribution. In the head and at the interface of the pile and slope are arranged a dial indicator, measure the horizontal displacement of the head and at the interface, and then can calculate the distribution of the horizontal displacement of the pile.

Table 1 Silt sand parameters

\begin{tabular}{|c|c|c|c|c|}
\hline$/ \mathrm{g} . \mathrm{cm}^{-3}$ & moisture & $\begin{array}{c}\text { porosity } \\
\text { ratio }\end{array}$ & $\begin{array}{c}\text { inner } \\
\text { friction } \\
/\left(^{\circ}\right) \\
\end{array}$ & $\begin{array}{c}\text { compression } \\
\text { modulus } \\
/ \mathrm{MPa} \\
\end{array}$ \\
\hline 1.64 & 10 & 0.875 & 35.3 & 5.71 \\
\hline
\end{tabular}

Table 2 Model pile parameters

\begin{tabular}{|c|c|c|c|}
\hline $\begin{array}{l}\text { Pile } \\
\text { length } \\
\text { /mm }\end{array}$ & $\begin{array}{c}\text { Pile } \\
\text { diameter } \\
/ \mathrm{mm}\end{array}$ & $\begin{array}{l}\text { Buried } \\
\text { depth } \\
/ \mathrm{mm}\end{array}$ & $\begin{array}{c}\text { Elastic } \\
\text { Modulus } \\
/ \mathrm{MPa}\end{array}$ \\
\hline 1000 & 46.1 & 950 & 30000 \\
\hline
\end{tabular}

\section{Test program}

To carry out different loading methods, foundation piles at different distances to the top surface of the slope and other tests, the force in the form of proposed and failure mode on under complex loads $45^{\circ}$ slope foundation pile, study its carrying properties and deformation mechanism. In practical engineering, building foundation piles both withstand the weight of the upper structure, but also to withstand wind loads and braking force and other horizontal loads. According to the actual working conditions, the development of this experiment Table 3 test loading program to study the impact of pre-applied vertical load bearing characteristics of pile level.

Table 3 Test load program

\begin{tabular}{|c|c|c|c|c|c|}
\hline \multirow[b]{2}{*}{ Test Pile No. } & \multicolumn{2}{|c|}{ Vertical load } & \multicolumn{2}{|c|}{ Horizontal load } & \multirow{2}{*}{$\begin{array}{l}\text { Piles distance } \mathrm{L} \\
\text { from the top of the } \\
\text { hill }\end{array}$} \\
\hline & $\begin{array}{c}\text { Load } \\
\text { Size }\end{array}$ & Load Properties & $\begin{array}{c}\text { Load } \\
\text { Size }\end{array}$ & Load Properties & \\
\hline \multirow{2}{*}{$\mathrm{P}_{1}$} & $P_{v}$ & Level Load & 0 & 0 & 0 \\
\hline & - & - & $P_{h}$ & Level Load & 0 \\
\hline \multirow{2}{*}{$\mathrm{P}_{2}$} & $\mathrm{P}_{\mathrm{v}}$ & Level Load & 0 & 0 & $1 \mathrm{~m}$ \\
\hline & - & - & $\mathrm{P}_{\mathrm{h}}$ & Level Load & $1 \mathrm{~m}$ \\
\hline \multirow{2}{*}{$\mathrm{P}_{3}$} & $P_{v}$ & Level Load & 0 & 0 & $2 \mathrm{~m}$ \\
\hline & - & - & $\mathrm{P}_{\mathrm{h}}$ & Level Load & $2 \mathrm{~m}$ \\
\hline
\end{tabular}

\section{Test equipment}

Loading apparatus of the present trial vertical loads imposed by the jack, and to ensure vertical load direction during the horizontal load is always vertical. Horizontal load by weight (a weight of $5.1 \mathrm{~kg} \approx 50 \mathrm{~N}$ ) to load, that is fixed in the trailer coupling is applied strand by means pulleys. Sectional model test instrument's arrangement is shown in Fig. 1.

Displacement measurement: It measured by dial indicator. The horizontal force in the vertical direction on the trailer coupling of steel beams, symmetrically fixed set two dial indicator to the measured vertical displacement pile; the horizontal direction of the force, and the slope of the slope more than $10 \mathrm{~cm}$ at each installation a dial indicator to measure the horizontal displacement. 
Pile stress measurement: the CM-2B multi-point static strain (programmable) fast acquisition and analysis strain gauges to measure strain gauges.

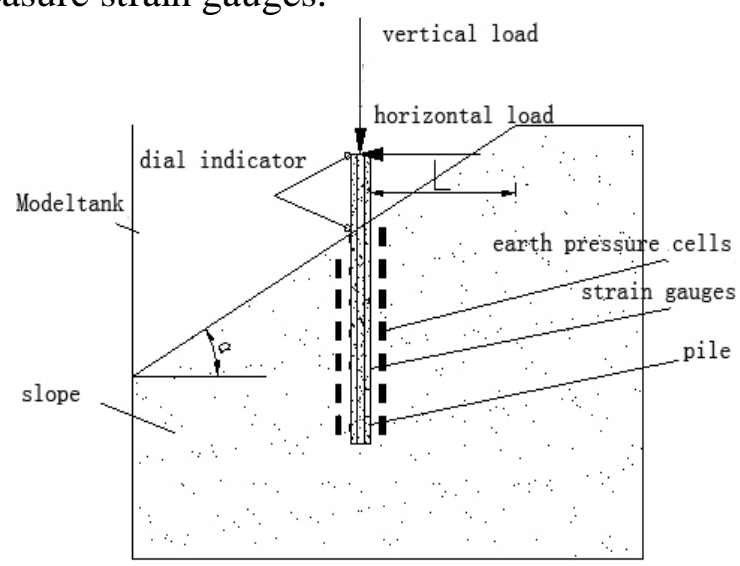

Fig.1 Profile of the model test instrument layout

\section{Test procedure}

The test uses chronic maintain load method, by using the vertical step by step the same amount of test pile load rating load of $0.3 \mathrm{kN}$, should be loaded so that the load transfer uniform, continuous, no impact. For the test pile, the first vertical load exerted by certain vertical loading device, and then kept constant vertical load, horizontal load is applied until the destruction by fixed pulley. The horizontal test load to allow the horizontal displacement pile $1 \mathrm{~cm}$ or broken as a termination load standards.

\section{Experimental results}

\section{The comparative analysis of bending moment working conditions}

Pile embedded strain gauges and strain gauges connected, can be measured horizontal load test pile under tensile and compressive strain value of each section to give the bending moment, which can draw the profile of the bending moment along the pile of Fig. 2, 3, 4 .By analyzing the experimental data shows that: at all levels load, since the test against the action of the soil around the pile, the bending moment values are positive and negative, to a certain depth will be reversed bending. Moments, while under the influence of vertical loads and horizontal loads, bending moment increases with the depth of the first (in the $\mathrm{C} 1$ strain gauge reaches a maximum at the moment) and then decreases to zero at E1 at last, showing Features flexible pile. With the change in position of test pile, changing moment. On the $45^{\circ}$ slope, when the horizontal load of $350 \mathrm{~N}$, at the moment at the $\mathrm{C} 1$ value $\mathrm{P}_{1}>\mathrm{P}_{2}>\mathrm{P}_{3}$.

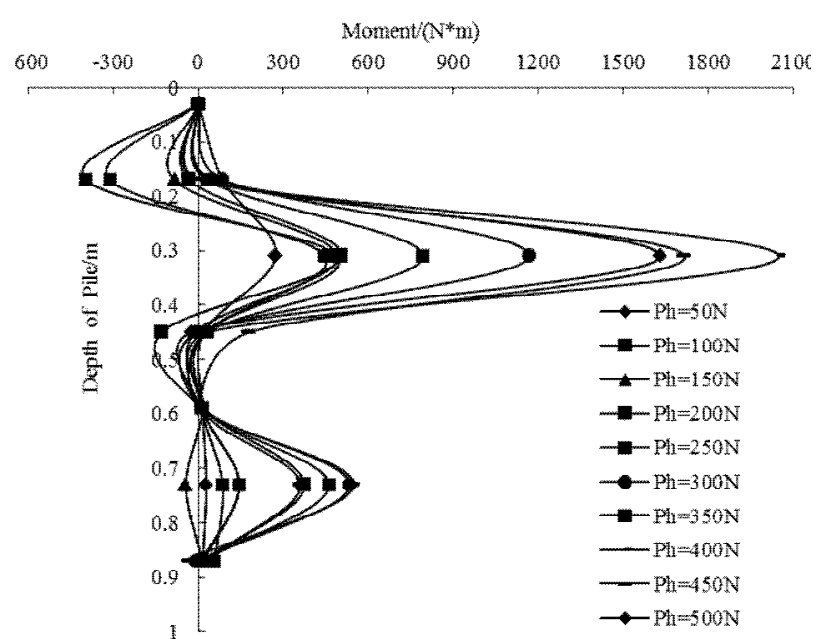

Fig.2 $\mathrm{P}_{1}$ pile bending moment

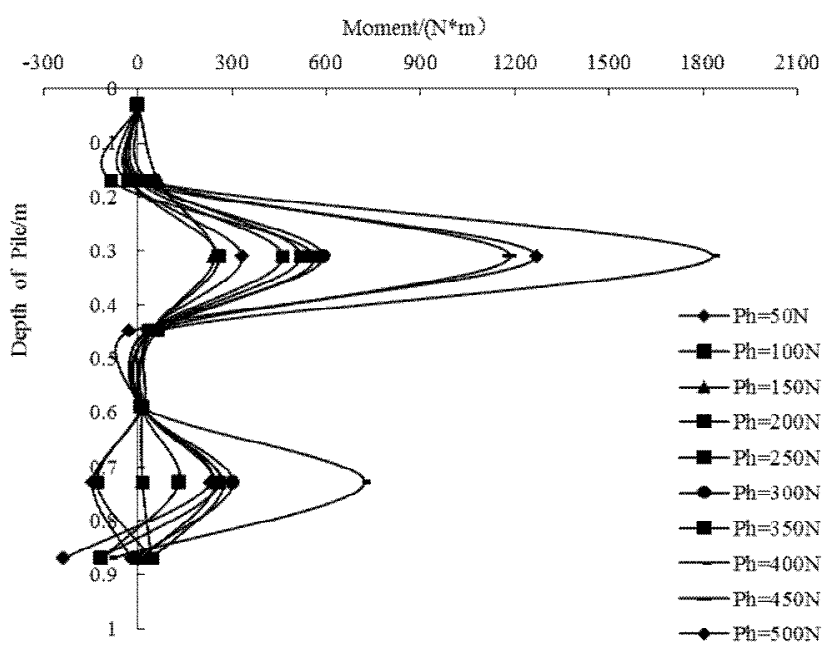

Fig.3 $\mathrm{P}_{2}$ pile bending moment 


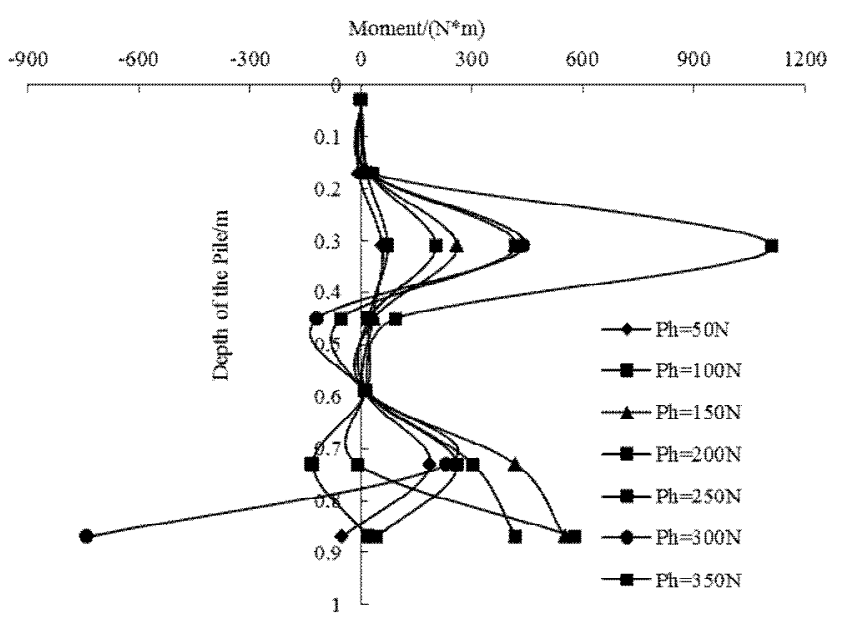

Fig. $4 \mathrm{P}_{3}$ pile bending moment

\section{Each pile friction condition comparative analysis}

Adjacent to the pile length between two strain gages for the study, the study calculated for each pile friction distribution along the pile as shown in Fig.5, 6, 7. On the $45^{\circ}$ slope, $\mathrm{P}_{1}$ pile located top of the slope, the pile side friction most obvious change, the reduced pile side friction value increases with depth first. When the horizontal load of $0.6 \mathrm{kN}$, in D1-E1 at the pile friction $\mathrm{P}_{1}>\mathrm{P}_{2}>\mathrm{P}_{3}$. When the horizontal load of $0.9 \mathrm{kN}$, in D1-E1 at the pile friction $\mathrm{P}_{1}>\mathrm{P}_{2}>\mathrm{P}_{3}$. Since the top of the pile during the test part is bare soil in vitro, this distance is no contact with the soil pile, so when that is loaded, pile side friction does not produce the maximum position at the top of the pile. P1, P2, P3 three test piles at the maximum horizontal load, both appear pile bottom side friction increases again the case, but this only occurs when the load exceeds a certain value.

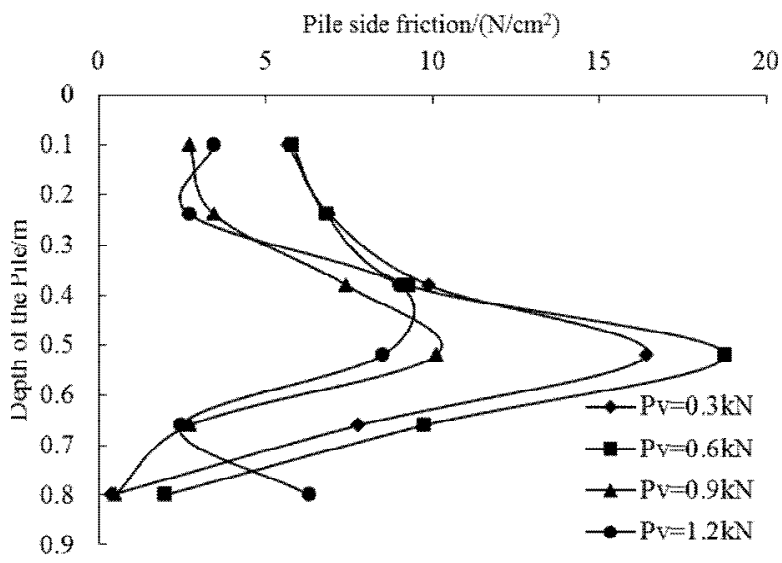

Fig.5 $\mathrm{P}_{1}$ pile side friction-depth curve

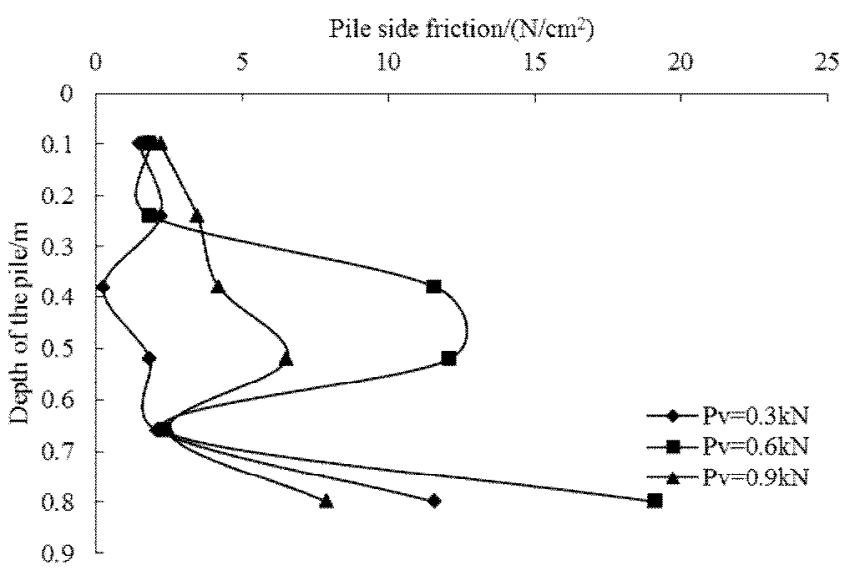

Fig.6 $\mathrm{P}_{2}$ pile side friction-depth curve

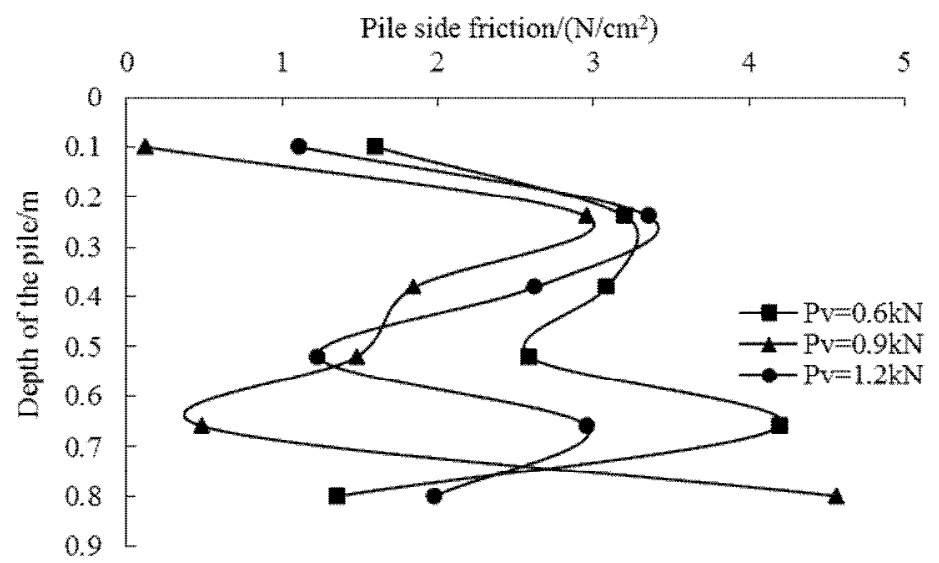

Fig.7 $\mathrm{P}_{3}$ pile side fiction-depth curve 


\section{Conclusion}

By loading equipment designed to study in the $45^{\circ}$ slope test pile in a different location, pile bearing characteristics of pile under vertical load and lateral load applied to the case. The following conclusions:

(1) Under the vertical loads, when the horizontal load and test pile gage position is the same, the point moment $\mathrm{P}_{1}>\mathrm{P}_{2}>\mathrm{P}_{3}$. Bending moment increases with decreasing depth of the first, the last place goes to zero at E1, bending moment mainly at a distance of 3/7 at the top of the pile.

(2) Test pile under vertical loads, horizontal loads to the pile horizontal displacement of less. Therefore, the level of impact on the single pile load bearing characteristics can be ignored.

(3) The maximum value of the side friction resistance of pile does not appear on top of the pile, $\mathrm{P}_{1}$ pile appears at the D1-E1, $\mathrm{P}_{2}$ pile appears at the $\mathrm{C} 1-\mathrm{D} 1, \mathrm{P}_{3}$ pile appears at the $\mathrm{B} 1-\mathrm{C} 1$. When the load is the same level, side $\mathrm{P}_{1}, \mathrm{P}_{2}, \mathrm{P}_{3}$ three test piles at the same position in the frictional resistance strain gauge value $\mathrm{P}_{1}>\mathrm{P}_{2}>\mathrm{P}_{3}$.

\section{Acknowledgement}

This work was supported by the National Natural Science Foundation of China (Grant No. Item-51508163), which is part of research project on the "Research on the Bearing Characteristic \& Deformation Mechanism of Pile Foundation on Hillside under Combined vertical and lateral loads".

\section{References}

[1] ANAGNOSTOPOULOS C, GEORGIADIS M. Interaction of axial and lateral pile response. Journal of Geotechnical Engineering Division, ASCE, Vol. 119(4), (1993). p. 793-798.

[2] W D Guo, GHEE E H. Behavior of axially loaded pile groups subjected to lateral soil movement. Foundation Analysis and Design: Innovative Methods, (2006), p.174-181.

[3] LIANG F Y, CHEN H B, CHEN S L. Influences of axial load on the lateral response of single pile with integral equation method. International Journal for Numerical and Analytical Methods in Geomechanics, Vol. 36(16), (2012), p. 1831-1845.

[4] Liu Cheng-xue. Behavior Analysis of Piles under Inclined Loads of free Galerkin method and its application. Changsha, Hunan University master's degree thesis, (2004).

[5] Gong Xian-bing, Yang Ming-hui, Zhao Ming-hua and others.High and steep mountain slope cross section of bridge pile foundation model test mechanism. Chinese Journal of Highway, Vol. 26 (2), (2013), p. 56-62.

[6] Zheng Gang, Wang Li, vertical and horizontal load loading level, the impact of the order on the bearing capacity. Geotechnical Engineering, Vol. 30(12), (2008), p. 1796-1804.

[7] Zhang Jian-wei, Kong qing-mei, Ma Jin-dong, Research on bearing characteristics of single pile on hillside under complex loads , Building Structure, Vol. 44 (16), (2014), p. 96-98.

[8] Ma Jin-dong, Zhang De-zhi, Zhang Jian-wei, Experimental Research lateral bearing behavior of reinforced concrete pile shape model. Building Structure, Vol. 44 (17), (2014), p.69-71. 